\title{
The Fall of the House of Usher: The Collapse of Roderick's Nostalgia Mechanism
}

\author{
Hong Zhang ${ }^{1}$ \\ ${ }^{1}$ School of Foreign Languages, Central South University, Changsha, China \\ Correspondence: Hong Zhang, School of Foreign Languages, Central South University, Changsha, China. E-mail: \\ zh_phyllis@163.com
}

Received: September 12, 2021

Accepted: October 20, 2021

Online Published: November 4, 2021

doi:10.5539/ells.v11n4p43

URL: https://doi.org/10.5539/ells.v11n4p43

\begin{abstract}
As an attractive Gothic tale of Edgar Allan Poe, The Fall of the House of Usher creates a mysterious and violent fall, leaving multiple interpretations on why the house of Usher collapsed suddenly. From the perspective of Roderick, the last inheritor of aristocratic Usher, the fall of Usher is more like his shaky nostalgia mechanism in front of discontinued situation. In his seemingly stable nostalgia mechanism, Mansion Usher, the narrator and Lady Madeline play core roles in meeting the needs of avoidance, attachment and idealization to construct a seemingly stable nostalgia mechanism. With the weird fall of Usher, Poe probes into the irrational nature of human, permeating his attention to warn the significance of balancing comfortable dream and reality.
\end{abstract}

Keywords: Edgar Allan Poe, The Fall of the House of Usher, Roderick, nostalgia mechanism

\section{Introduction}

In his short life, Edgar Allan Poe (1809-1849) wrote about 70 short tales in the genre of detective, science and others, leading American literature to new writing fashion with his mysterious and grief writing style. Among them, The Fall of the House of Usher occupies a seminal place in the development of Gothic novel with its great value of Gothic aesthetics in Mansion Usher. Timmerman comments it belongs to "those few stories that seem to elicit nearly as many critical interpretations as it has readers" (2003, p. 227). The Fall of the House of Usher develops with the memory of the narrator who is invited into isolated Usher which stays as a monument of ancient aristocratic tradition. In the wheel of history, Usher leaves last aristocratic Roderick Usher and Madeline Usher who suffer from an uncanny disease. After burying Madeline, Roderick becomes more agitated in panic cries. As it develops uncannily, in a tempestuous yet sternly beautiful night, Lady Madeline revives from the death with a bloody and white robe, walks to her twin brother Roderick, and finally brings Roderick into death together. Soon, the house of Usher is fragmented and swallowed up by the deep and dank lake. In retrospect, the interpretations on The Fall of the House of Usher can be roughly concluded as four perspectives. First of all, the obvious Gothic style attracts studies on the exploration of the factors about Usher terror, such as David Punter states that "terror is the claustrophobic fiction of Poe, where the individual is alone with the insupportable" (1998, p. 235), ensuring Poe's great achievement on terror tale. Secondly, it's about the characteristics of Usher with Psychology. Some critics attribute the fall of Usher to reason's breaking, while others relate the Usher structure to human's conscious. Most strikingly, Richard Wilbur in "The House of Poe" proposes that Usher house is body of Roderick when the inside space is the wildest fantasy in his brain. The whole tale is a journey towards deep self. Moreover, as the sociological critic trend develops, scholars focus more on the manner of Lady Madeline to guess the general personality and textual significance of Poe's female characters. Also, there are scattered tentative interpretations probing from the perspective of "things" in Usher. Scholars believe that there is close interactive relation between characters and thing in Usher, and things in Usher occupy the central position with its own agency, in consequence, to attribute the fall of Usher to the rebellion of Usher "things". On the whole, studies on Usher are intellectually rich with numerous articles, but there is not a systematic analysis to overview the relation of Roderick, Lady Madeline, the narrator and mansion Usher.

From the perspective of Roderick, The Fall of the House of Usher is more like the collapse of his shaky nostalgia in which he establishes so-call comfort zone and the most ideal relationship with the narrator and Lady Madeline in order to get rid of the new changes in the external environment. Nostalgia, coming from two Greek roots "nostos" and "algos", is coined by Swiss doctor Johannes Hofer in 1688 to "define the sad mood originating 
from the desire for return to one's native land" (Boym, 2001, p. 26). In today's research on Nostalgia, scholars tend to regard nostalgia as "an adaptive response to stress or change" (Batcho, 2013, p. 170), "a defence mechanism in a time of accelerated rhythms of life and historical upheaval" (Boym, 2001, p. 14), sharing some features with Sigmund Freud's concept of defense to "describe the ego's struggle against painful or unendurable ideas of affects" (p. 41). Taking a step further, nostalgia is seen as the psychological mechanism in front of the uncomfortable inconsistency brought from the outside change, having "complicated organic structure, cognitive schema and adaptive systems which are limitedly operated" (Qi \& Zhu, 2019, p. 70). Basically, nostalgia is motivated by three strategies that are avoidance, attachment and idealization so as to realize self-identification. Under the fear from discontinuity of social identity, nostalgic subject tends to avoid the crowd, and to rely on nostalgia objects to build ideal framework of time and space an ideal relationship with familiar others to meet the need of "attachment" so as to ensure the security of social identity.

\section{Roderick: The Deserted Aristocracy Experiencing Discontinuity}

The Fall of the House of Usher is published in 1839 when "Horace Bushnell predicted that if slaves are ever freed, they would die off by the end of the century" (Dougherty, 2001, p. 4) in which the word "they" indicates both the slave and the master. Under the background of precarious future of old aristocracy, Roderick Usher, as the inheritor in the ancient family being noted for a peculiar sensibility of temperament, suffers from a mental disorder. According to the first impression described by the narrator, Roderick Usher is not like the one in the childhood but "the cadaverous complexion, a pair of large and luminous eyes, a thin and very pallid lips" (Poe, 2004, p. 371). His manner presents incoherent and inconsistent shouting hysterically "I shall perish, I must perish in this deplorable folly. Thus, thus, and not otherwise, shall I be lost. I dread the events of future, not in themselves, but in their results" (Poe, 2004, p. 246). As an aristocrat in the new world, Roderick is trapping in the fear of abandonment that is "the unshakable belief that our friends and loved ones are going to desert us or don't really care about us" (Tyson, 2006, p. 16). With forthcoming change in the outside society, Roderick has to undertake the responsibility to keep the graceful manner as a symbol of deserted aristocrat.

In response to fear of abandonment, nostalgia mechanism first emphasizes to rebel against the linear time, "the time of history and progress" (Boym, 2001, p. 15). The ideal time established by the nostalgia subject is "a yearning for a different time-the time of childhood" (Ibid.). The first method Roderick applies to get rid of discontinuity is to return to childhood when all the things are the same graceful and prosperous as usual. So, the narrator, as a friend in the boyhood, plays a key role in assisting Roderick to contact with Usher's original glory, which can explain why the narrator received a strange letter from a distant part of the country. The letter expresses that Roderick has "an earnest desire to see me, as his best, and indeed his only personal friend, with a view of attempting, by the cheerfulness of my society, some alleviation of his malady" (Poe, 2004, p. 243). For another, the narrator, as an outlander, is the messager to deliver the advanced ideas of outside, breaking the long isolation of Usher family from the outside world. Although Roderick tries to comfort himself by connecting with the narrator, the foreign fashion brought by narrator betrays Roderick's insistence as old aristocrat. So, as the narrator recalls that "more bitterly did I perceive the futility of all attempt at cheering a mind from which darkness" (Poe, 2004, p. 248), the narrator cannot go into the heart of Roderick because the narrator symbolizes the outside society which is opposite to the rule of aristocratic family. His existence, as the symbol of modern society, brings comfort as well as pressure and threat to Roderick.

Except for the ideal to return to past, Roderick is indulgent in keeping the aristocratic elegance. He can only accept exalted and complicated arts as his family has so strict requirement for the blood that the entire family only lies in the direct line of decent. Roderick cannot torture "the odors of all flowers" and "even a faint light", but "there were but peculiar sounds, and these from stringed instruments, which did not inspire him with horror" (Poe, 2004, p. 246). His exclusive selection on art proves that "nostalgia is fetishism" (Hook, 2012, p. 231). Frequently, certain things can provide the one memory to the past that plays a protective function. Fetishistic nostalgia is necessarily conservative for those who meet the potential castrated identity to deny the threatening reality. In Usher, the fetishistic "feel good" is summed up in his ancient taste in art. In the field of music, except for certain effects of old guitar, his auditory nerve is too morbid to allow other music. The old guitar cannot play a cheerful music but the fantastic and sorrow melody. He indulges in the long-improvised dirges, especially the last waltz of Von Weber, which brings people a sense of perversion and pain instead of the original pleasure the music should bring. In painting, Roderick prefers the style of vagueness with fancy brood, permeating the sense of depression that cannot be expressed by writing. For instance, one of his oppressive paintings shows "the interior of an immensely long and rectangular vault or tunnel" without outlet, torch and any artificial light but "a flood of intense rays rolling throughout" (Poe, 2004, p. 248), bathing the whole painting in a ghastly inharmonious splendor just like the imbalance between present decay and past glory of Usher. Compared with 
music and painting, poetry can convey Roderick's addiction to past memory more completely. His impromptu chant of "The Haunted Palace" is "an allegory of mental struggle and collapse" (Voloshin, p. 423). The king of glorious palace is endangered by "evils things in robes of sorrow" (p. 249). The contrast between past "blush and bloom" (Ibid.) and the present desolation witnesses the merciless history. Nobody but the deserted aristocracy can remember the palace blooming the incomparable glory. In a sense, the glorious palace in the poem symbolizes the past life of Usher house. Roderick is the victim who is trapped in the fetishism about the memory of splendid past. Also, his only acceptance on certain style of miserable art limits himself in the melancholy manner, resulting that he cannot escape from the prison, the comfort zone, the mansion that symbolizes the noble identity.

\section{Desolate Mansion: The Comfort Zone to Avoid the Crowd}

Besides, the ideal space of nostalgia mechanism emphasizes to carry comfortable memory of subject in a real image. In the eyes of Usher family, the mansion records the transmitted patrimony, symbolizing the ancient and inbred family lineage, and the past honor of the family, as well a comfort zone of the family where they can be reasonable to resist against the new change in the outside world. At the beginning of the story, the house is enveloped in the isolated antiquity as the narrator recalls that "with the first glimpse of the building, sense of insufferable gloom pervaded my spirit" (Poe, 2004, p. 242). The isolated antiquity meets the basic need to construct nostalgic space in the theory of Boym that "the object of romantic nostalgia must be beyond the present space of experience, somewhere in the twilight of the past or on the island of utopia where time has happily stopped, as on an antique clock" (p. 39). When the present is defined as complicated, dirty, and full of conflict, the ideal space is simple, pure and harmony, relieving subject's nostalgic discomfort in present environment and maintain self-continuity. In the story, the spirit of Usher family is put into the house itself. The house to some extents is the embodiment of the person. Through the desolate mansion, Roderick can keep a safe distance with the reality. At the beginning, the narrator on horseback passes through a "dreary tract of country" (Poe, 2004, p. 242) in which the tract is the path to communicate with the outside, especially representing modernity as Bakhtin in his Forms of Time and Chronotope in the Novel proposes that a tract encounters the spatial and temporal paths of the most varied people and thus has the potential to be the junction of different spaces and times. But the tract in front of the mansion is not operated until the coming of narrator. When the modernity brought from the coming of the narrator reaches out to the point of the antiquity, the house cannot accommodate itself to communicate with the outside, and thus start to appear "a barely perceptible fissure extending from the roof to the lake" which can be found by "a scrutinizing observer" (Poe, 2004, p. 244), symbolizing the inharmonious modernity in comparison with the long-hidden mansion, as well implying the future of the house. The house refuses to negotiate with the tract and still keeps in the isolated and conservative position.

Following the memory of narrator, a series of desolate scenes on the outside gradually unfold like the scroll such as "the black walls", "the vacant eyelike windows", "a few white trunks of decayed trees" (Poe, 2004, p. 242) and the surroundings, setting the tone of the story as lifeless depression. From far to near, "its principal feature seemed to be that of an excessive antiquity" with "fungi overspreading the whole exterior, webwork hanging from the eaves", indicating that the house should be collapsed during time. However, although the house of Usher echoes the voice of death, it still stands as a monument avoiding from the crowd. Seen from the inside, the room of Roderick is "very large and lofty" with "feeble gleams of encrimsoned light" where "the windows are long, narrow, and pointed, and at so vast a distance from the black oaken floor as to be inaccessible from within" (Poe, 2004, p. 245). The capacious but empty setting in the room leaves a sense of depression without verve and vitality, influencing that "the general furniture was profuse, comfortless, antique, and tattered" (Ibid.). Those familiar things are covered by a sorrow mask. Even if the books and musical instruments cannot bring any vitality to the scene.

In short, from the outside to the inside, the general image of the house is antique and comfortless, but it's still the cradle of Roderick providing a decent life without worrying about food or clothing. An isolated space is the basis to construct a comfortable relation with others. For Roderick, the house is the ideal location to construct the nostalgia with its value as the only inherited honor and treasure of family, representing the glorious past. At the beginning, there is still a servant waiting for the narrator to usher him into the presence of his master. But after that time, the servant disappears without reason, implying that the aristocratic system starts to collapse. Moreover, after the death of Madeline who provides Roderick a sense of belonging, the fissure of his comfort zone widens, indicating that the avoidance from reality and nostalgic indulgence is pushing one to a morbid stage instead of the new change in the society. 


\section{Lady Madeline: Significant Others to Keep Security}

Nostalgic subject is inclined to avoid those elements related to discontinuity, but also to attach to other familiar things or people to realize sense of belonging. On the basis of ideal home, "the nostalgic reverie is always peopled" (qtd. in Sedikides et al., 2004, p. 212). The need of attachment requires a completed nostalgia to possess an ideal personal relationship so as to ensure a simple, controllable and comfortable space away from the crowd. In mansion Usher, there are three characters to establish the relationship among the self, the other and significant others, namely, the key protagonist Roderick, the narrator who is the messager of childhood and new society, and Lady Madeline whose death is the direct reason of Usher's fall. According to relational identity theory proposed by Shapiro, "neither personal identity nor social identity is constructed in a vacuum. We constantly position ourselves in relation to others and define ourselves according to these perceived relations" (p. 636). In other words, the other is the reflection of the self. But in the relationship between the other and the self, there is another important identity that is significant others who play a vital role in one's life such as relatives, friends and partners. As the only family of Roderick, Madeline is the one who shares the same background with Roderick and enables his fear for abandonment being understood possible. In the eyes of Roderick, Madeline is the significant others whom he can depend on for survival. Through the existence of Madeline, Roderick can convince that his position is not dangerous and continue to stay at his comfort zone. But as what Charles Taylor says "we are all aware of how identity can be formed or malformed through the course of our contact with significant others" (p. 36), the identity can be destroyed with the death of significant others. Therefore, in this story, since Madeline gets sick, the space to conduct nostalgia has begun to develop the fissure. As the ending indicates that Roderick and all the things related to old Usher come to death with the corpse of Madeline together, meanwhile symbolizing the fall of Roderick into his own complex of nostalgia.

Even if Madeline is the key character in this tale as the significant others, Madeline is still the marginal character who only presents three times in the story. Madeline is caught in the double binds that are aristocratic system and Roderick's nostalgia mechanism. Particularly, Madeline and Roderick are in the relationship of symbiosis and binary oppositions. Unlike the owner of the heritage, Madeline, as an aristocratic lady, cannot say a word even before her death. The power is manifested by discourse. Without the generation, accumulation and dissemination of discourse, the power of Lady Madeline as an individual will not be established and implemented. Discourse is strongly bounded area of social knowledge, consequently, "historian ... consists in making all these discourses visible in their strategic connections" (Foucault, 1980, p. 38). But in the house of Usher, all the manner of Madeline is described by narrator, illustrating that her discourse is excluded from other forms of discourse, such as male discourses. In order to portray a home as warm resting place of love and care for breadwinner, the noble lady is elevated as a pure virgin figure on the moral temple. Whether for Roderick or the narrator, Madeline is the embodiment of past glory who can provide security for Usher. She is gradually buried under the magnificent aristocratic mansion. But she does not yield to the confinement and always resist against her fate like a female hero. Although her disease has long baffled the skill of the doctor, "she had steadily borne up against the pressure of her malady, and had not betaken herself finally to bed" (Poe, 2004, p. 247). Except her tough resistance against death, she always wanders around the house to remind Roderick of her existence, making him trickle many passionate tears. Even in the coffin, Madeline still struggles to escape from the destiny. "The rending of her coffin, and the grating of the iron hinges of her prison" (Poe, 2004, p. 259) claim her indictment to the family and the society. Her awakening brings the fall of the whole family, which is her ultimate oppression and worst betrayal of her brother. Madeline is the significant others to bring the stern comfort in the eyes of Roderick, but he never considers that there will be the fissure in this seemingly harmonious symbiosis. When the significant others are not those in the ideal manner that is simple, warm and submissive, the change, betrayal and death of significant others result in the destruction of the whole nostalgia mechanism in the dream of Roderick. Her breaking of the coffin brings the collapse of the feudal aristocracy, revealing the most violent resistance of the oppressed.

\section{Conclusions}

The Fall of the House of Usher is the reflection of Roderick's nostalgia mechanism. As a deserted aristocrat, he suffers from fear of abandonment in front of the rapid shift that old aristocracy occupies no the central position in the hierarchy any longer. Therefore, Roderick activates the psychological mechanism to defend himself from the outside danger that mainly lies in nostalgia. His education in the aesthetics gives rise to the exclusive acceptance on certain sentimental arts with which Roderick immerses himself into the eulogy of the past honor. Moreover, although the outside danger urges Roderick to accept the forthcoming change, he chooses to regress to the mansion inherited from the ancient forefather where is the comfort zone for him. Like its owner, the house tends to be conservative and thus experiencing the conflict with progressing modernity. Essentially, the ideal 
location to contain Roderick's nostalgia is too ramshackle to provide the expected comfort. Apart from the future collapse of the house, the ideal personal relationship built in Roderick's nostalgia is also on the verge of collapse. As the significant others, Madeline is the only one sharing the same identity with Roderick to mirror the seemingly secure Usher, furnishing the tranquilizer that convinces that Roderick is not alone to face the coming change. However, Madeline is a lady with rebellious spirit who does not give passive obedience to the destiny but to break through the confined space from the inside. Her awakening before the death symbolizes the most vital betrayal, in consequence, her violent death brings Roderick to fall as a corpse, manifesting her silent victory.

In fact, nostalgia can provide people a temporary refuge to get rid of the stressful reality. But "nostalgia is a sentiment of loss and displacement, but it is also a romance with one's own fantasy" (Boym, 2001, p. 13). Nostalgia is the existence to seduce more than convince. Those, like the modern Roderick who is preoccupied with the past memory instead of looking ahead and accepting the new world, are doomed to fall into fragmentation in the nostalgia. The Fall of the House of Usher is actually a richly ambiguous text whose uncanny experience reveal Poe's warning for later generation to balance fantasy and reality. Although the outside world is sharply changing, people should be adapting themselves to the new as evolution is survival of the fittest.

\section{References}

Batcho, K. I. (2013). Nostalgia: The Bittersweet History of a Psychological Concept. History of Psychology, 16(3), 165-176. https://doi.org/10.1037/a0032427

Boym, S. (2001). The Future of Nostalgia. New York: Basics Books.

Dougherty, S. (2001). Foucault in the House of Usher: Some Historical Permutations in Poe's Gothic. Papers on Language and Literature, 37(1), 3-24.

Foucault, M. (1980). Power/Knowledge: Selected Interviews and Other Writings 1972-1977. Edited by Colin Gordon. New York: Pantheon Books.

Freud, A. (1993). The Ego and the Mechanisms of Defence. Trans. Baines, Cecil. UK: Karnac Books.

Hook, D. (2012). Screened History: Nostalgia as Defensive Formation. Peace and Conflict: Journal of Peace Psychology, 18(3), 225-239. https://doi.org/10.1037/a0029071

Poe, E. A. (2004). The Fall of the House of Usher. The Collected Tales \& Poems of Edgar Allan Poe (pp. 242-260). London: Wordsworth Editions.

Punter, D. (1998). Terror. In M.-R. Marie (Ed.), The Handbook to Gothic Literature (pp. 235-240). London: Macmillan Press LTD.

Qi, T., \& Zhu, Y. S. (2019). Affect, Cognition and Identity: Re-Theorizing Nostalgia from a Schematic Perspective. Journal of Anhui University, 3, 60-70. https://doi.org/10.1080/24740500.2019.1705233

Sedikides, C. et al. (2004). Nostalgia: Conceptual Issues and Existential Functions. In G. Jeff et al. (Eds.), Handbook of Experimental Existential Psychology (pp. 205-219). New York: The Guilford Press.

Shapiro, D. L. (2010). Relational Identity Theory: A Systematic Approach for Transforming the Emotional Dimension of Conflict. American Psychologist, 65(7), 634-645. https://doi.org/10.1037/a0020004

Taylor, C. (1994). Multiculturalism: Examining the Politics of Recognition (Edited by Amy Gutmann). Princeton: Princeton University Press. https://doi.org/10.2307/j.ctt7snkj

Timmerman, J. H. (2003). House of Mirrors: Edgar Allan Poe's "The Fall of the House of Usher". Papers on Language and Literature, 39(3), 227-244.

Tyson, L. (2006). Critical Theory Today: A User-Friendly Guide (pp. 11-37). New York: Routledge.

\section{Copyrights}

Copyright for this article is retained by the author, with first publication rights granted to the journal.

This is an open-access article distributed under the terms and conditions of the Creative Commons Attribution license (http://creativecommons.org/licenses/by/4.0/). 